\title{
Effect of nursing telemonitoring on the knowledge of obese women: clinical trial
}

\author{
Efeito do telemonitoramento de enfermagem no conhecimento de mulheres obesas: ensaio clínico \\ Resultado del telemonitoreo de enfermería en el conocimiento de mujeres obesas: un ensayo clínico
}

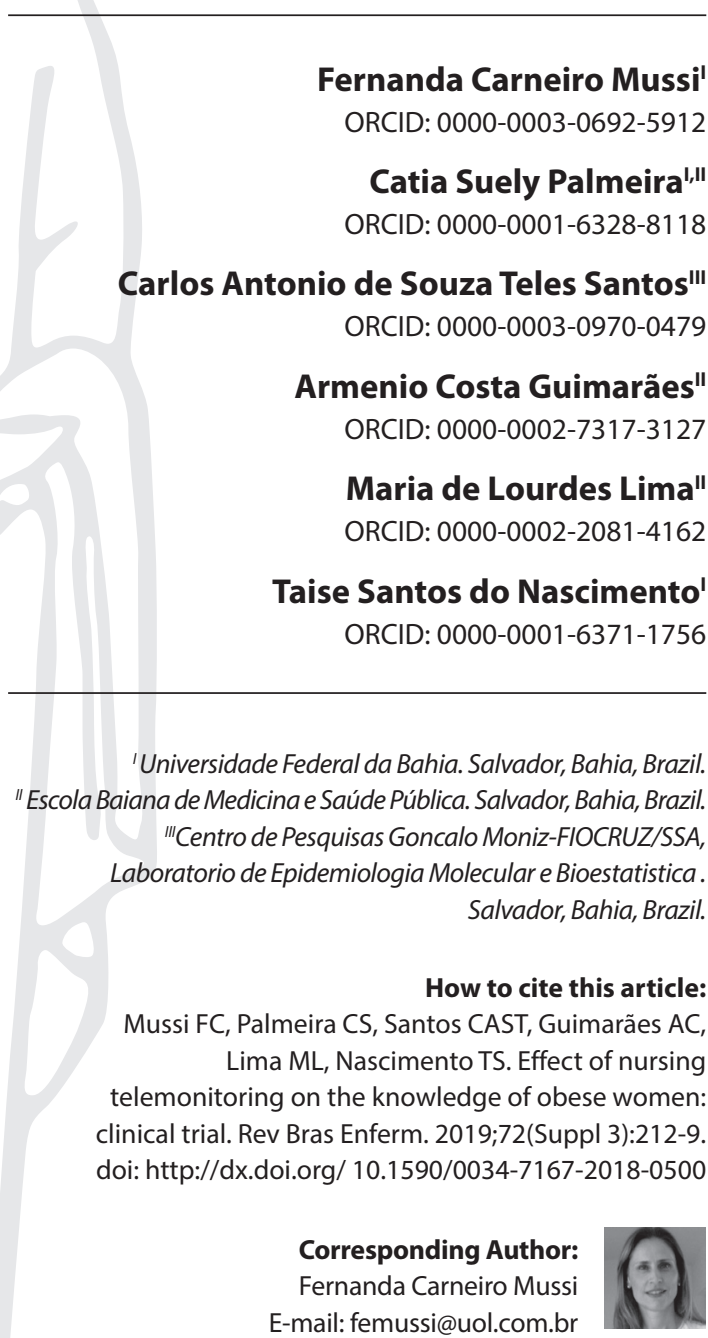

Submission: 06-26-2018 Approval: 02-26-2019

\begin{abstract}
Objective:To assess the effectiveness of remote monitoring in the knowledge of overweight women. Method: Randomized clinical trial with 101 women, randomly assigned to the control group ( $C G=50)$ and to the intervention group $(I G=51)$. The IG received educational intervention over the telephone, during three months and routine follow-up in the service, while the CG only received conventional follow-up. The knowledge was assessed by a specific questionnaire. Data were analyzed by the Robust Linear Regression Model, adopting a statistical significance of $5 \%$. Results: In the intragroup assessment, an increase in the correct answers with a statistically significant difference was observed only for the IG in the domains: "Concept and causes of overweight," "Complications of overweight" and "Eating habits." In the intergroup comparison, an increase in the average knowledge was verified in the same domains for the IG $(p \leq 0.005)$. Conclusion: nursing telemonitoring contributed positively to the improvement of women's knowledge.

Descriptors: Obesity; Knowledge, Health Education; Telenursing; Clinical Trial.
\end{abstract}

\section{RESUMO}

Objetivo: Avaliar a efetividade do monitoramento remoto de enfermagem na melhora do conhecimento de mulheres com excesso de peso. Método: Ensaio clínico randomizado, com 101 mulheres, alocadas aleatoriamente no grupo controle $(G C=50)$ e no grupo intervenção $(G l$ $=51)$. $\mathrm{O} \mathrm{Gl}$ recebeu intervenção educativa por telefone durante três meses e acompanhamento de rotina no serviço, e o GC, apenas acompanhamento convencional. O conhecimento foi avaliado por questionário específico. Os dados foram analisados pelo Modelo de Regressão Linear Robusto, adotando-se significância estatística de 5\%. Resultados: Na avaliação intragrupo houve aumento de acertos com diferença estatisticamente significante apenas para o Gl nos domínios: "Conceito e causas do excesso de peso", “Complicações do excesso de peso" e "Hábitos alimentares". Na comparação intergrupos, verificou-se para o Gl aumento na média do conhecimento nos mesmos domínios ( $p \leq 0,005$ ). Conclusão: o telemonitoramento de enfermagem contribuiu positivamente para a melhora do conhecimento das mulheres.

Descritores: Obesidade; Conhecimento, Educação em Saúde; Telenfermagem; Ensaio Clínico.

\section{RESUMEN}

Objetivo: Evaluar la eficacia del monitoreo a distancia de enfermería en la mejora del conocimiento de mujeres con sobrepeso. Método: Ensayo clínico aleatorizado, realizado con 101 mujeres, asignadas aleatoriamente en grupo control $(G C=50)$ y en grupo de intervención (GI $=51$ ). El GI recibió intervención educativa por teléfono, durante tres meses, y seguimiento de rutina en el servicio, mientras que el GC recibió solo el seguimiento convencional. Se evaluó el conocimiento mediante un cuestionario específico. Los datos se analizaron utilizando el Modelo de Regresión Linear Robusto, adoptando la significancia estadística del 5\%. Resultados: En la evaluación intragrupal, hubo un aumento en los aciertos con una diferencia estadísticamente significante solo para el Gl en los dominios: "Concepto y causas del sobrepeso", "Complicaciones del sobrepeso" $y$ "Hábitos alimenticios". En la comparación intergrupal, se verificó que el Gl aumentó la media del conocimiento en los mismos dominios $(p \leq 0,005)$. Conclusión: el telemonitoreo de enfermería contribuyó positivamente a la mejora del conocimiento de las mujeres. Descriptores: Obesidad; Conocimiento, Educación en Salud; Teleenfermería; Ensayo Clínico. 


\section{INTRODUCTION}

Obesity has reached epidemic proportions almost everywhere in the world, becoming one of the leading causes for increased chronic diseases, disabilities and preventable deaths ${ }^{(1-2)}$. It is now estimated that over half a billion adults are obese and that at least 2.8 million die each year from overweight ${ }^{(2-5)}$. Brazil has also shown an increasing prevalence of overweight and obesity ${ }^{(6)}$.

Defined as excessive accumulation of body fat, obesity is caused by the interaction between genes and environmental, psychosocial, economic, behavioral, endocrine and metabolic factors ${ }^{(1)}$. The increased consumption of high-calorie, high-sugar, low-saturated, and low-nutrient foods combined with reduced physical activity has grown overweight rates ${ }^{(3)}$.

This complex clinical condition affects all ages and socioeconomic groups with serious social and psychological repercus$\operatorname{sions}^{(7-8)}$ and organic complications that reduce quality of life ${ }^{(9)}$. The higher the body mass index, the worse the overall health status and the greater the limitations for performance at work, in domestic services and in daily activities ${ }^{(10)}$.

Considering its complex and multifactorial etiological nature, chronicity and the damages caused, the management of obesity is one of the main concerns of public health and a huge challenge for health professionals ${ }^{(11)}$. The control of this problem depends on changes in eating habits, the practice of physical activity and attention to the psychological aspects, usually represented by long-established behavioral and social patterns that are difficult to modify ${ }^{(8)}$.

Given that humans live in complex social structures that influence personal choices, the approach of the overweight person should consider all factors that may represent a barrier to healthy behaviors $^{(12)}$. The knowledge about the illness and treatment processes, although it does not guarantee behavior change ${ }^{(13)}$ nor ensure adherence to the recommended lifestyle, can be a facilitator for the choices necessary to preserve an appropriate body weight ${ }^{(14)}$. However, much of the population's knowledge about nutrition and physical activity comes from media coverage, which is not always based on reliable scientific information and may lead to wrong choices ${ }^{(15)}$.

In health care for people with chronic health problems, educational measures emerge as one of the essential strategies to help them make decisions about self-care and overcome their problems. Nurses have always had a prominent role in the educational measures developed in their work process ${ }^{(16)}$.

Despite the diverse approaches developed by government health organizations to improve information for weight management, only few studies have explored the knowledge of overweight people about the disease and control measures. The use of strategies to learn and improve the knowledge level of women about the disease and control measures are fundamental, remote monitoring included.

Remote monitoring allows nurse-client interaction through devices such as the telephone. This mode of health care and education at a distance contributes to overcoming barriers of distance and time and is expanding the care of people with chronic diseases, enhancing the capacity of interaction among the subjects involved, in a fast and accessible way ${ }^{(17)}$. However, the educational intervention for overweight women through this technology has not yet been assessed. The national and international literature do not have studies on nursing telemonitoring for overweight people, which was verified in a literature review, carried out in November 2017, in the last 10 years, using the keywords "telenursing" - "telenfermagem"; "obesity" - "obesidade"; educação em saúde - health education", on databases Medical Literature Analysis and Retrieval System Online (MEDLINE); Cumulative Index to Nursing \& Allied Health Literature (CINAHL) and Latin American and Caribbean Health Sciences Literature (Lilacs).

\section{OBJECTIVE}

To assess the effectiveness of remote monitoring in the knowledge of overweight women.

\section{METHOD}

\section{Ethical aspects}

The study was approved by the Research Ethics Committee of the Nursing School of the Federal University of Bahia and by the Brazilian Clinical Trials Registry. All participants read and signed the informed consent form.

\section{Design, local and period of study}

Controlled clinical trial ${ }^{(18)}$, randomized with two groups, Intervention Group (IG) and Control Group (CG). The study was developed in an outpatient service for the treatment of overweight people, a reference for users of the Unified Health System, located in the city of Salvador, Bahia, Brazil. In this outpatient clinic, the followup is done by a multidisciplinary team (doctor, nurse, nutritionist and psychologist) and consists of individual appointments and educational activities in the waiting room. The research was carried out from July 2016 to March 2017. In the initial period of data collection there were 348 people registered in the service, being 317 women and 31 men.

\section{Participants in the study}

We chose overweight women because they represent $91 \%$ of the people that attend the service. Initially, the records of all 317 women were consulted to identify the eligibility criteria. Inclusion criteria were women with a body mass index (BMI) $\geq 25 \mathrm{~kg} / \mathrm{m} 2$, older than 18 and younger than 60 years old, and those attending at least one appointment in the last 12 months. The exclusion criteria were women with cognitive difficulties and severe psychiatric disorders who were unable to respond to the forms, used weight loss drugs (Sibutramine and Orlistat), underwent bariatric surgery or did not have a cell phone.

All 117 eligible women were invited to participate in the survey. Of these, 16 women did not show up for data collection, resulting in a final sample of 101 women. After data collection for baseline formation, women were randomly divided into two groups, group A (Intervention Group) and group B (Control Group).

The allocation criterion was block randomization according to the age group, since age is a variable that could influence the 
response to treatment. Randomization occurred as follows: in the first block, aged $<50$ years, there were 51 women, 26 of whom were allocated in group $A$ (IG) and 25 in group $B(C G)$. The same procedure was applied for the second block with women in the age range $\geq 50$ years: 25 women in group $A(I G)$ and 25 in group $B$ (CG). To ensure the allocation of the participants was concealed, the designation for the blocks was performed by a statistician, who did not participate in the intervention sessions. At the end, IG was composed of 51 participants, while CG had 50 participants (Figure 1). After the groups were formed at the baseline, we verified whether the characteristics of the participants guaranteed comparability between the groups.

Once the CG and the IG were established, the control group continued with the follow-up appointments in the service while the intervention group, in addition to these appointments, received remote monitoring through telephone calls.

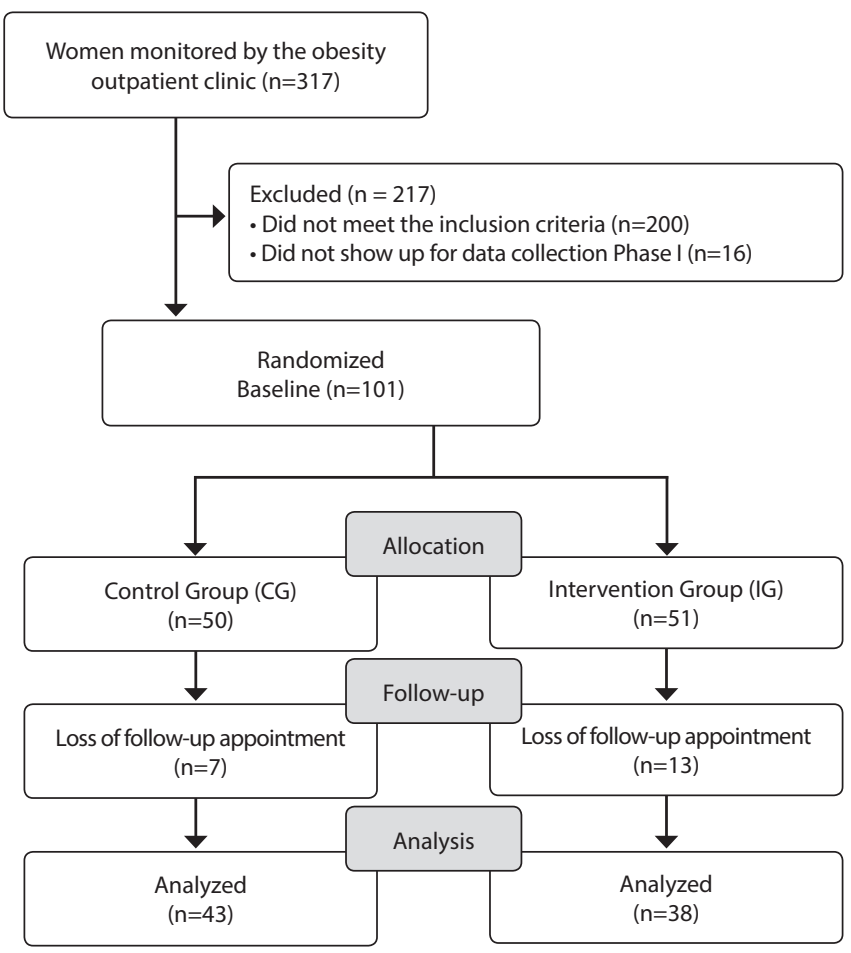

Figure 1 - Flowchart of the participants in the study, Salvador, Bahia, Brazil, 2017

\section{Data collection}

\section{Constitution of the baseline}

Data were collected by a group of seven trained interviewers, in dates previously scheduled, and 20 women were invited for each meeting until the complete baseline formation. Before the application of the data collection instruments, the women participated in a workshop that explained the objectives and procedures of the research, addressed expectations of orientation and the difficulties experienced for weight reduction.

The women recruited for the baseline were interviewed; two instruments were used, one for sociodemographic characterization and the other to assess the knowledge about overweight.
The first one consisted of closed-ended questions about age, self-declared race/color, origin, occupation, schooling, work, monthly family income, and number of income dependents.

The knowledge assessment instrument contained 20 closedended questions comprising four domains: 1) concept and causes of overweight (four questions); 2) complications (four questions); 3) recommended eating habits (nine questions) and 4) practice of physical activity (3 questions). The questions were created based on the guidelines of the Scientific Societies ${ }^{(11)}$ and manuals of the Ministry of Health ${ }^{(8)}$ and on the experience of the population monitored at the place of study. The form was made by the researchers due to the inexistence of an instrument validated for the objective of the study and was reviewed by specialists and adjusted after a pilot test with three women.

\section{Intervention protocol}

Remote monitoring (RM) lasted three months and was carried out by weekly telephone contact to provide guidelines on obesity and the necessary care for weight control, besides motivating the participants to adhere to the treatment, allowing the expression of doubts and comments and addressing specific issues related to their needs.

A weekly themed guideline for weight control was developed based on guides from scientific societies ${ }^{(8,11)}$ and consultation with specialists. The sequence of content exposure was flexible when it was necessary, allowing the participant to interrupt to ask questions, clarify doubts and add information.

The understanding of the contents was verified during the call by asking the women to report their understanding of the topics on the agenda. The language used in the guideline was well though through, so the information was objective, attractive and easy to understand. To help the team with the calls, a Telephone Call Guide was developed, used for each call, before the implementation of the Weekly Themed Guidance.

$A$ researcher and two undergraduate nursing students conducting a scientific research participated in the intervention. All the calls were made together with this researcher in order to guarantee an appropriate approach. At the end of the intervention, the women in the IG and CG were re-assessed, and the knowledge assessment instruments were reapplied.

\section{Data processing and analysis}

The categorical variables were analyzed in absolute and relative frequencies, and the continuous variables, in means and standard deviation. Pearson's Chi-square test or Fisher's exact test were applied to verify if CG and IG were homogeneous regarding sociodemographic characteristics.

The Pearson Chi-square test was used to compare the proportion of correct answers for each question, for women in the IG and CG, before and after the RM (intragroup analysis).

To estimate the effect of the intervention on knowledge, the correct answers for each domain of the instrument were summed, obtaining a score of correct answers before and after the RM. To analyze the difference in the intragroup correct answers, the Robust Linear Regression Model was used, and to 
verify the difference of intergroup correct answers, the range of intragroup correct answers was generated (gain of knowledge = correct answers after RM minus the correct answers before $\mathrm{RM})$. This range was considered in the intergroup comparison (gain of knowledge of the IG compared with CG after the RM), using the Robust Linear Regression Model. Statistical significance was given by $\mathrm{p} \leq 0.05$.

Data were entered in the Statistical Package for Social Science (IBM SPSS version 18.0) and analyzed in Stata (version 12.0).

Based on the mean of the weight difference and respective standard deviation (SD), before and after RM, for CG and IG, the power of the sample was estimated considering $n 1=50$ (CG) and $n 2=51$ (IG) and alpha of 0.05 , reaching the power of $80.8 \%$.

\section{RESULTS}

The mean age of the 101 participants was $47.8(S D=9.0)$ years, with a predominance of women in the age group 50-59 years (47.5\%). Most people were self-declared black and brown (93.1\%), with high school or some high school (62.4\%), in a conjugal situation without a partner (51.5\%), remunerated activity (54.5\%) and family income less than or equal to three minimum wages (87.1\%). No statistically significant difference was found between the sociodemographic characteristics of women in the CG and the IG.

Table 1 shows the proportion of correct answers for each question in the domains "Concept and causes of overweight" and "Complications of overweight," before and after monitoring, according to CG and IG. In both domains, before and after the intervention, the number of correct answers to the questions was predominant for both groups.

In the comparison of intragroup correct answers in the domain "Concept and causes of overweight," there was an increase in correct answers to all questions for IG after RM, with statistical significance for obesity-related questions $(p=0.000)$ and the existence of a relationship between overweight and genetics ( $p$
$=0.019)$. Regarding the $C G$, we observed an increase in the proportion of correct answers in the re-assessment, except for one question, but in no situation there was a statistically significant difference (Table 1).

As to the knowledge of the complications of overweight, both groups presented satisfactory knowledge, even before the intervention, according to the percentages of correct answers above $70.0 \%$ in all four questions of this domain. In the intragroup comparison after RM, IG showed a higher percentage of correct answers in the four questions of the domain, with a statistically significant difference for two of them. The CG analysis showed a higher proportion of correct answers in three of the four questions with statistical significance for one question $(p=0.032)$ and a lower proportion of correct answers for one question ( $p$ $=0.039$ ) (Table 1).

Table 2 shows the percentages of correct answers of CG and IG before and after the intervention related to the questions of domains "Measures related to eating habits" and "Measures related to physical activity." The women of both groups, when assessed in the baseline, presented a high percentage of correct answers, higher than $74.0 \%$ in all the questions. After the intervention, the CG increased the frequency of correct answers of both domains, but no statistically significant difference was found. The IG after RM not only increased the proportion of correct answers in most questions regarding the baseline, but also showed a statistically significant difference in two questions.

In the intragroup assessment, per domain of the knowledge instrument, we observed an increase in the correct answers of IG in the areas "Concept and causes of overweight," "Complications of overweight" and "Eating habits" $(p<0.05)$. No increase in the correct answers was found in the CG with statistically significant differences in any of the domains (Table 3).

After the intervention, in the intergroup comparison, IG showed an increase in the average knowledge about overweight in the four domains, with statistical significance in the domains Concept and Causes, Complications and Eating Habits (Table 3).

Table 1 - Comparison of intragroup correct answers on the knowledge about concept, causes and complications of overweight before and after remote monitoring, Salvador, Bahia, Brazil, 2017

\begin{tabular}{|c|c|c|c|c|c|c|}
\hline \multirow[b]{3}{*}{ Questions } & \multicolumn{6}{|c|}{ Frequency of correct answers } \\
\hline & \multicolumn{2}{|c|}{ CG } & \multicolumn{3}{|c|}{ IG } & \multirow[b]{2}{*}{$\begin{array}{c}p \\
\text { value }\end{array}$} \\
\hline & $\begin{array}{c}\text { Before } \\
(n=50) \\
\%\end{array}$ & $\begin{array}{c}\text { After } \\
(n=42) \\
\%\end{array}$ & $\underset{\text { value* }}{p}$ & $\begin{array}{c}\text { Before } \\
(n=51) \\
\%\end{array}$ & $\begin{array}{c}\text { After } \\
(\mathbf{n}=38) \\
\%\end{array}$ & \\
\hline \multicolumn{7}{|c|}{ Domain: concept and cause of overweight } \\
\hline Obesity is considered a disease & 96.0 & 97.6 & 0.667 & 96.0 & 100.0 & 0.000 \\
\hline Relationship between overweight and genetics (heredity) & 74.0 & 67.4 & 0.487 & 68.6 & 89.5 & 0.019 \\
\hline Relationship between overweight and eating habits & 96.0 & 97.7 & 0.645 & 92.2 & 97.4 & 0.291 \\
\hline Relationship between overweight and physical activity & 86.0 & 88.4 & 0.732 & 90.2 & 97.4 & 0.180 \\
\hline \multicolumn{7}{|l|}{ Domain: Overweight complications } \\
\hline Hypertension may be related to being overweight & 86.0 & 95.3 & 0.134 & 92.2 & 100.0 & 0.078 \\
\hline Diabetes may be related to being overweight & 70.0 & 88.4 & 0.032 & 78.4 & 94.7 & 0.031 \\
\hline Problems in bones and muscles, osteoarthritis and spinal pain may be related to being overweight & 90.0 & 93.0 & 0.609 & 90.2 & 100.0 & 0.047 \\
\hline Sleep disorder may be related to being overweight & 80.0 & 60.5 & 0.039 & 74.5 & 84.2 & 0.271 \\
\hline
\end{tabular}

Note: CG: Control Group; IG: Intervention group; *P value obtained by the Pearson Chi-square Test. 
Table 2 - Comparison of intragroup correct answers in questions about measures related to eating habits and physical activity, before and after remote monitoring, Salvador, Bahia, Brazil, 2017

\begin{tabular}{|c|c|c|c|c|c|c|}
\hline \multirow[b]{3}{*}{ Questions } & \multicolumn{6}{|c|}{ Frequency of correct answers } \\
\hline & \multicolumn{2}{|c|}{ GC } & \multicolumn{4}{|c|}{ GI } \\
\hline & $\begin{array}{c}\text { Before } \\
\text { (n=50) } \\
\%\end{array}$ & $\begin{array}{c}\text { After } \\
\text { (n=42) } \\
\%\end{array}$ & $\underset{\text { value* }}{p}$ & $\begin{array}{c}\text { Before } \\
\text { (n=51) } \\
\%\end{array}$ & $\begin{array}{c}\text { After } \\
\text { (n=38) } \\
\%\end{array}$ & $\underset{\text { value* }}{p}$ \\
\hline \multicolumn{7}{|l|}{ Domain: measures related to eating habits } \\
\hline To eat three main meals a day and three more snacks in the intervals helps lose and control weight & 80.0 & 81.4 & 0.865 & 84.3 & 97.4 & 0.042 \\
\hline Less than three meals a day helps lose and control weight & 74.0 & 83.7 & 0.259 & 80.4 & 94.7 & 0.051 \\
\hline The amount of food consumed in meals influences weight control & 88.0 & 88.4 & 0.952 & 92.2 & 100.0 & 0.078 \\
\hline Ideal number of meals per day to control weight & 76.0 & 88.4 & 0.125 & 74.5 & 78.9 & 0.630 \\
\hline To lose weight in a healthy way one should only eat salads and vegetables & 96.0 & 93.0 & 0.525 & 82.4 & 92.1 & 0.186 \\
\hline $\begin{array}{l}\text { To lose weight in a healthy way one should eat varied foods including salads, vegetables, fruits, } \\
\text { cereals, grains and meats in adequate portions }\end{array}$ & 96.0 & 100.0 & 0.190 & 98.0 & 100.0 & 0.380 \\
\hline $\begin{array}{l}\text { Replacing meals such as lunch and dinner for snacks (sandwiches, salads etc.) helps reduce } \\
\text { weight in a healthy way }\end{array}$ & 98.0 & 100.0 & 0.356 & 94.1 & 100.0 & 0.127 \\
\hline Food preparation techniques to lose weight & 96.0 & 100.0 & 0.190 & 100.0 & 97.4 & 0.251 \\
\hline $\begin{array}{l}\text { Frequency of small consumption of pies, butter and sandwich cookies for weight control }<3 \text { times } \\
\text { a week }\end{array}$ & 90.0 & 97.7 & 0.135 & 88.2 & 97.4 & 0.111 \\
\hline \multicolumn{7}{|l|}{ Domain: Measures related to physical activity } \\
\hline The practice of physical activity alone is enough to lose weight & 94.0 & 95.3 & 0.783 & 94.1 & 100.0 & 0.127 \\
\hline $\begin{array}{l}\text { The ideal way to lose weight is to perform moderate physical activity, } 3 \text { to } 5 \text { times a week >30 } \\
\text { minutes/day }\end{array}$ & 92.0 & 95.3 & 0.522 & 100.0 & 94.7 & 0.999 \\
\hline $\begin{array}{l}\text { To walk } 2 \text { hours straight in a single day of the week has the same benefit as walking } 30 \text { minutes } \\
\text { every day }\end{array}$ & 86.0 & 93.0 & 0.281 & 94.1 & 97.4 & 0.458 \\
\hline
\end{tabular}

Note: CG: Control Group; IG: Intervention group; *P value obtained by the Pearson Chi-square Test.

Table 3 - Comparison of intragroup and intergroup correct answers by knowledge domain about overweight before and after remote monitoring, Salvador, Bahia, Brazil, 2017

\begin{tabular}{|c|c|c|c|c|c|c|c|c|c|c|}
\hline \multirow[b]{3}{*}{ Domains } & \multirow[b]{3}{*}{$\begin{array}{c}\text { Before } \\
\text { (n= 50) } \\
X(S D)\end{array}$} & \multirow{2}{*}{\multicolumn{2}{|c|}{ Control Group }} & \multirow{2}{*}{\multicolumn{3}{|c|}{ Intragroup Comparison }} & \multirow{2}{*}{\multicolumn{2}{|c|}{ Intervention Group }} & \multirow{2}{*}{\multicolumn{2}{|c|}{ Intergroup Comparison }} \\
\hline & & & & & & & & & & \\
\hline & & $\begin{array}{c}\text { After } \\
\text { (n=43) } \\
X \text { (SD) }\end{array}$ & $\begin{array}{l}\text { Coef.* } \\
(\mathrm{SE})^{* *}\end{array}$ & $p$ value ${ }^{* * *}$ & $\begin{array}{c}\text { Before } \\
(n=51) \\
X(S D)\end{array}$ & $\begin{array}{c}\text { After } \\
(\mathbf{n}=38) \\
X(S D)\end{array}$ & $\begin{array}{l}\text { Coef.* } \\
(\mathrm{SE})^{* *}\end{array}$ & $p$ value ${ }^{* * *}$ & $\begin{array}{l}\text { Coef.* } \\
(\mathrm{SE})^{* *}\end{array}$ & $p$ value ${ }^{* * *}$ \\
\hline Concept and causes & $3.5(0.6)$ & $3.5(0.6)$ & $-0.01(0.13)$ & 0.948 & $3.5(0.8)$ & $3.8(0.4)$ & $0.38(0.14)$ & 0.007 & $0.33(0.11)$ & 0.005 \\
\hline Complications & $3.3(1.1)$ & $3.4(0.7)$ & $0.11(0.19)$ & 0.565 & $3.3(1.1)$ & $3.8(0.5)$ & $0.43(0.17)$ & 0.010 & $0.42(0.14)$ & 0.004 \\
\hline Eating habits & $8.0(1.4)$ & $8.3(1.1)$ & $0.34(0.26)$ & 0.190 & $7.9(1.5)$ & $8.6(0.6)$ & $0.64(0.23)$ & 0.008 & $0.25(0.19)$ & 0.191 \\
\hline Physical activity & $2.7(0.5)$ & $2.8(0.4)$ & $0.12(0.10)$ & 0.227 & $2.9(0.3)$ & $2.9(0.3)$ & $0.04(0.06)$ & 0.544 & $0.08(0.08)$ & 0.295 \\
\hline
\end{tabular}

Note: *Coefficient; **Standard error; *** p value obtained by the Robust Linear Regression Model.

\section{DISCUSSION}

In this study, we found that women had a high level of knowledge in all items about the concepts, causes and complications of overweight, feeding and physical activity before remote monitoring, as 15 out of the 20 items of the instrument showed a percentage of correct answers equal to or higher than $80 \%$, in three equal to or above $70 \%$, and in two above $60.5 \%{ }^{(18)}$. This success can be explained in part by the fact that the participants are monitored by a multidisciplinary team and have incorporated a lot of information throughout the follow-up treatment. The high level of knowledge about the contents to be addressed in the educational intervention posed an even bigger challenge. The confirmation of what people know about their health-disease process is important so that health care professionals can establish a dialogue guided by the needs of those to whom they provide care.
Notably, the percentage of correct answers increased in practically all the questions, mainly in the intervention group. Some women in the IG, after the educational intervention, totaled $100.0 \%$ correct answers in six of the twenty questions, while this same percentage was identified in the CG for only two questions. The comparative analysis between the groups also showed that women in the IG had an increase in the percentage of correct answers in three questions $(p=0.000)$.

There are not enough studies on the knowledge of overweight people about the problem and treatment at a national and international level, so it was not possible to compare these results with other investigations. Knowledge is an important prerequisite for guiding self-care, and we may consider that most women had adequate information for decision-making about weight control.

Regarding the overweight concept, the IG that already had a good knowledge before the monitoring of obesity as a disease 
(96.0\%) presented an increase in the frequency of correct answers, reaching $100.0 \%(p=0.0000)$. For Visscher et $\mathrm{al}^{(19)}$, individuals seeking help already perceive obesity as a risk factor and disease. This knowledge is important because once the problem is recognized as a disease, its treatment must also be considered, since one of the important aspects to improve self-care is the increase in the capacity to understand the health-related phenomena.

We observed an increase in the frequency of correct answers for IG after monitoring of the question about genetics as the etiological factor of obesity ( $p=0.0190)$ in the block of questions about the complications of overweight. It is noteworthy that the recognition of this aspect in the genesis of obesity can contribute to a more comprehensive understanding in facing this aggravation and preventing it from descendants.

We also noticed after the intervention an increase in the correct answers in the four questions of the block about complications of overweight for IG and, in three of them, for CG. However, for IG, the frequency of correct answers was higher compared with CG in the question about the present relationship between bone and muscle problems, osteoarthritis and spinal pain with excess weight $(p=0.0190)$. It is noteworthy that the recognition of this aspect in the genesis of obesity can contribute to a more comprehensive understanding in facing this aggravation and preventing it from descendants. The percentage of correct answers was very good for both groups regarding the association of overweight with diabetes mellitus and arterial hypertension.

As to the knowledge about the complications of obesity, the percentages of correct answers were close to those found in a research carried out in New York, which assessed the knowledge of overweight black and Hispanic adults about the consequences of obesity for health and identified that the majority knew about the risk of hypertension (94\%), diabetes (96\%), musculoskeletal pain and problems (89\%), and sleep apnea $(89.0 \%)^{(20)}$. A cross-sectional study carried out in Texas with 1,420 low-income women aged between 16 and 40 years, who intended to become pregnant, found that they did not know the health risks associated with obesity, which could put them at risk of developing diabetes or hypertension in the years before conception ${ }^{(21)}$. According to the same study, $43 \%$ of women believed that some people were born fat and little could be done about it, and $76 \%$ of women were unaware of what a healthy diet was. The study by Cardoso et $\mathrm{al}^{(22)}$, conducted with women in an infertility clinic, found limited knowledge about the effects of obesity and its relationship with endometrial and breast cancer (38.5\%).

Knowledge about a particular health outcome may influence the search for treatment and/or increase adherence to treatment ${ }^{(23)}$. The true perception of obesity as a disease and risk factor can contribute to effective obesity prevention and management strategies, and rates will continue to increase as long as individuals, society and professionals misinterpret the severity of excess weight ${ }^{(19)}$. Thus, health professionals, potential educators, need to be at the forefront of health education practices.

Regarding the dietary knowledge, most women in both groups showed a high percentage of correct answers to the questions before monitoring. For most of them the correct answers increased after the intervention, although with no statistical significance.
These data reflect the beneficial effect of the intervention and seem to show that women recognized the importance of diet in the treatment, mainly in the questions that deal with the amount of food consumed in the meals, the importance of the consumption of varied foods and of not replacing meals for snacks, and the correct way of preparing food. We observed that knowledge about nutrition was significantly associated with adherence to a given dietary pattern and a lower prevalence of obesity ${ }^{(14)}$. For the authors, knowledge about diet influences eating habits, regardless of socioeconomic factors, and it is a tool to promote healthier choices.

The finding that the mean of intragroup correct answers, before and after the RM, according to the domains of the knowledge instrument about the excess weight, showed better performance, in the IG, in the questions regarding "Concept and cause, "Complications" and "Eating Habits" $(p=0.000)$, and the mean of intergroup correct answers also showed a better performance, in the IG, in the questions about "Concept and Cause" and "Complications," highlighting the benefits of remote monitoring.

Effective educational interventions can lead people to reflect upon the problem, to understand their reality, stimulating them to find solutions and find therapeutic paths adapted to their daily life ${ }^{(23-24)}$. Despite some criticism about the low resolution of individual measures for weight control considering the obesogenic environment ${ }^{(25)}$, individualized educational approaches can guide and motivate each person toward a sustainable transformation of healthy practices necessary to face the problem.

There was a high percentage of correct answers regarding physical activity, which is one of the pillars in the treatment of obesity ${ }^{(26)}$. Knowledge gaps about this measure for weight control could constitute a barrier to its achievement, as well as a challenge for health professionals ${ }^{(27)}$. A study of obese and non-obese adult women identified a lack of awareness of the consequences associated with sedentary lifestyle, and obese women were less likely to enjoy physical activity and were only inclined to do so when they needed to reduce weight ${ }^{(28)}$. Thus, intervention programs that contribute to the valorization of physical activity and to the basic knowledge about the form and intensity of the exercises and their benefits have great value.

The benefits observed in this study regarding the increase in the knowledge about overweight through the educational intervention by remote monitoring indicate the therapeutic potential of this tool, corroborating other studies developed with other groups of people in condition of illness ${ }^{(29)}$.

\section{Limitations of the study}

The study also brought reflections upon its limits. It is noteworthy that the knowledge assessment about obesity considered relevant aspects, but not the full range of information that may contribute to the self-care of women. Another limitation refers to the use of an instrument to assess the knowledge constructed by the authors and appreciated by specialists in the field, given the inexistence of instruments validated in the literature for this purpose. The duration of the intervention may also not have been enough to increase the number of correct answers about knowledge. We highlight the limit of the knowledge assessment 
Effect of nursing telemonitoring on the knowledge of obese women: clinical trial Mussi FC, Palmeira CS, Santos CAST, Guimarães AC, Lima ML, Nascimento TS.

in only one moment in the follow-up time of the women after the intervention. These limitations can be overcome in future researches with better instruments of knowledge measurement, greater number of participants and different temporal measures. The scarcity of studies that used telemonitoring as an educational strategy with people with obesity made it difficult to compare the results of this study.

\section{Contributions to the field of nursing, health or public policy}

Despite the limitations mentioned, this study contributes to the nursing practice, especially to the field of health education and to increasing the knowledge of women in the intervention group. It also contributes to strengthening the nursing telemonitoring as a viable tool in clinical practice, especially in primary care.

\section{CONCLUSION}

This study showed that both groups presented a high level of knowledge about excess weight in the basal period, but the increase was more expressive in the intervention group when comparing the intragroup and intergroup correct answers, before and after the RM, according to the domains of the knowledge instrument on overweight. The study reinforces nursing telemonitoring as a valuable educational intervention strategy.

\section{FUNDING}

National Council for Scientific and Technological Development (Conselho Nacional de Desenvolvimento Científico e TecnológicoCNPQ), process 421599/2016-2.

\section{REFERENCES}

1. Hruby A, Manson JE, Qi L, Malik VS, Rimm EB, Sun Q, et al. Determinants and consequences of obesity. Am J Public Health. 2016;106(9):165662. doi: 10.2105/AJPH.2016.303326

2. Hruby A, Hu FB. The epidemiology of obesity: a big picture. Pharmacoeconomics. 2015;33(7):673-89. doi: 10.1007/s40273-014-0243-x

3. Lakerveld J, Mackenbach J. The upstream determinants of adult obesity. Obes Facts. 2017;10(3):216-22. doi: 10.1159/000471489

4. Schmidt MI, Duncan BB, Silva GA, Menezes AM, Monteiro CA, Barreto SM, et al. Chronic non-communicable diseases in Brazil: burden and current challenges. Lancet. 2011;377(9781):1949-61. doi: 10.1016/S0140-6736(11)60135-9

5. Finucane MM, Stevens GA, Cowan MJ, Danaei G, Lin JK, Paciorek CJ, et al. National, regional, and global trends in body-mass index since 1980: systematic analysis of health examination surveys and epidemiological studies with 960 country-years and $9 \cdot 1$ million participants. Lancet. 2011;377(9765):557-67. doi: 10.1016/S0140-6736(10)62037-5

6. Ministério da Saúde (BR). Secretaria de Vigilância em Saúde. Departamento de Vigilância de Doenças e Agravos não Transmissíveis e Promoção da Saúde. Vigitel Brasil 2015: vigilância de fatores de risco e proteção para doenças crônicas por inquérito telefônico: estimativas sobre frequência e distribuição sociodemográfica de fatores de risco e proteção para doenças crônicas nas capitais dos 26 estados brasileiros e no Distrito Federal em 2015 [Internet]. Brasília: Ministério da Saúde; 2016 [cited 2017 Nov 18]. Available from: http://bvsms. saude.gov.br/bvs/publicacoes/vigitel_brasil_2015.pdf

7. Wirth A, Wabitsch M, Hauner H. The prevention and treatment of obesity. Dtsch Arztebl Int. 2014;111(42):705-13. doi: 10.3238/arztebl.2014.0705

8. Ministério da Saúde (BR). Secretaria de Atenção à Saúde. Departamento de Atenção Básica. Estratégias para o cuidado da pessoa com doença crônica: obesidade [Internet]. Brasília: Ministério da Saúde; 2014 [cited 2017 Nov 18] (Cadernos de Atenção Básica, nº 38). Available from: http://bvsms.saude.gov.br/bvs/publicacoes/estrategias_cuidado_doenca_cronica_obesidade_cab38.pdf

9. Segula D. Complications of obesity in adults: a short review of the literature. Malawi Med J [Internet]. 2014[cited 2017 Nov 18];26(1):20-24. Available from: https://www.ncbi.nlm.nih.gov/pmc/articles/PMC4062780/

10. Pataky Z, Armand S, Müller-Pinget S, Golay A, Allet L. Effects of obesity on functional capacity. Obesity (Silver Spring). 2014;22(1):56-62. doi: 10.1002/oby.20514

11. Associação Brasileira para o Estudo da Obesidade e da Síndrome Metabólica (Abeso). Diretrizes Brasileiras de Obesidade 2016. 4th ed. São Paulo: Abeso; 2016.

12. Gortmaker SL, Swinburn B, Levy D, Carter R, Mabry PL, Finegood D, et al. Changing the future of obesity: science, policy and action. Lancet. 2011;378(9793):838-47. doi: 10.1016/S0140-6736(11)60815-5

13. Serafim TS, Jesus ES, Pierin AMG. Influence of knowledge on healthy lifestyle in the control of hypertensive. Acta Paul Enferm. 2010;23(5):658-64. doi: 10.1590/S0103-21002010000500012

14. Bonaccio M, Di Castelnuovo A, Costanzo S, De Lucia F, Olivieri M, Donati MB, et al. Nutrition knowledge is associated with higher adherence to Mediterranean diet and lower prevalence of obesity. Results from the Moli-sani study. Appetite. 2013;68:139-46. doi: 10.1016/j. appet.2013.04.026

15. Alves L, Melo DHC, Melo JF. Análise do conhecimento nutricional de adolescentes, pré e pós atividade educativa. Rev Em Extensão [Internet]. 2009 [cited 2017 Jul 18];8(2):68-79. Available from: www.seer.ufu.br/index.php/revextensao/article/view/20532

16. Ritter CB, Aires M, Rotolli A, Santos JLG. Grupo como tecnologia assistencial para o trabalho em enfermagem na saúde coletiva. Saúde Transf Soc [Internet]. 2014 [cited 2017 Nov 12];5(3):83-90. Available from: http://incubadora.periodicos.ufsc.br/index.php/saudeetransformacao/ article/view/2494 
17. Kuriakose JR. Telenursing an emerging field. Int J Nurs Educ [Internet]. 2011 [cited 2016 Nov 12];3(2):52-5. Available from: http://www. indianjournals.com/ijor.aspx?target=ijor:ijone\&volume $=3 \&$ issue $=2 \&$ article $=016$

18. Pereira SM, Barreto ML. Estudos de intervenção. In: Almeida Filho N, Barreto ML, organizadores. Epidemiologia e saúde: fundamentos, métodos, aplicações. Rio de Janeiro: Guanabara Koogan; 2012. p. 2015-24.

19. Visscher TL, Lakerveld J, Olsen N, Küpers L, Ramalho S, Keaver L, et al. Perceived health status: is obesity perceived as a risk factor and disease? Obes Facts. 2017;10(1):52-60. doi: 10.1159/000457958

20. Winston GJ, Caesar-Phillips E, Peterson JC, Wells MT, Martinez J, Chen X, et al. Knowledge of the health consequences of obesity among overweight/obese black and hispanic adults. Patient Educ Couns. 2014;94(1):123-7. doi: 10.1016/j.pec.2013.09.022

21. Berenson AB, Pohlmeier AM, Laz TH, Rahman M, Saade G. Obesity risk knowledge, weight misperception and diet and health-related attitudes among women intending to become pregnant. J Acad Nutr Diet. 2016;116(1):69-75. doi: 10.1016/j.jand.2015.04.023

22. Cardozo ER, Neff LM, Brocks ME, Ekpo GE, Dune TJ, Barnes RB, et al. Infertility patients' knowledge of the effects of obesity on reproductive health outcomes. Am J Obstet Gynecol. 2012;207(6):509.e1-509.e10. doi: 10.1016/j.ajog.2012.08.020

23. Sweileh WM, Zyoud SH, Abu Nab'a RJ, Deleq MI, Enaia MI, Nassar SM, et al. Influence of patients' disease knowledge and beliefs about medicines on medication adherence: findings from a cross-sectional survey among patients with type 2 diabetes mellitus in Palestine. BMC Public Health. 2014;14:94. doi: 10.1186/1471-2458-14-94

24. Torres HC, Souza ER, Lima MHM, Bodstein RC. Educational intervention for self-care of individuals with diabetes mellitus. Acta Paul Enferm. 2011;24(4):514-9. doi: 10.1590/S0103-21002011000400011

25. Dias PC, Henriques P, Anjos LA, Burlandy L. Obesity and public policies: the Brazilian government's definitions and strategies. Cad Saúde Pública. 2017;33(7):e00006016. doi: 10.1590/0102-311X00006016

26. Fogelholm M. Physical activity, fitness and fatness: relations to mortality, morbidity and disease risk factors. A systematic review. Obes Rev. 2010;11(3):202-21. doi: 10.1111/j.1467-789X.2009.00653.x

27. Burgess E, Hassmén P, Pumpa KL. Determinants of adherence to lifestyle intervention in adults with obesity: a systematic review. Clin Obes. 2017;7(3):123-35. doi: 10.1111/cob.12183

28. Leone LA, Ward DS. A mixed methods comparison of perceived benefits and barriers to exercise between obese and non-obese women. J Phys Act Health [Internet]. 2013[cited 2017 Nov 28];10(4):461-9. Available from: https://www.ncbi.nlm.nih.gov/pmc/articles/PMC3904548/

29. Souza-Jr VD, Mendes IA, Mazzo A, Godoy S. Application of telenursing in nursing practice: an integrative literature review. Appl Nurs Res. 2016;29:254-60. doi: 10.1016/j.apnr.2015.05.005 